NUKHBATUL 'ULUM : Jurnal Bidang Kajian Islam

Vol. 4, No. 2 (2018) : Hal. 120-134

Website: https://journal.stiba.ac.id

ISSN : 2685-7537 (online) 2338-5251 (Printed)

\title{
SEJARAH MAZHAB FIKIH DI ASIA TENGGARA
}

\section{Muhammad Ikhsan}

Sekolah Tinggi Ilmu Islam dan Bahasa Arab (STIBA) Makassar,

Jl. Inspeksi PAM Manggala-Antang Makassar

Email :muhikhsan@stiba.ac.id

\begin{tabular}{ll}
\hline Keywords : & \multicolumn{1}{c}{ ABSTRACT } \\
\cline { 2 - 2 } History of Islamic & This study explains the historical aspects of the spread of Islamic \\
Jurisprudence, Shafi'i School, & Jurisprudence in South East Asia which cannot be separated from the \\
Southeast Asian Islam, & history of the spread of Islam itself in Southeast Asia. It also describes \\
Compilation of Islamic Law. & the existence of Islamic jurisprudence as indicated by the intellectual \\
& works of Southeast Asian Islamic Jurisprudence scholars, especially in \\
& the Shafi'i School. The existence of Islamic jurisprudence was then \\
& developed in the form of influences that influence the National \\
& Constitution in South East Asia, especially in Indonesia, in the form \\
& of Compilation of Islamic Law.
\end{tabular}


NUKHBATUL 'ULUM : Jurnal Bidang Kajian Islam

Vol. 4, No. 2 (2018) : Hal. 120-134

Website: https://journal.stiba.ac.id

ISSN : 2685-7537 (online) 2338-5251 (Printed)

\section{PENDAHULUAN}

tidak dapat dilepaskan dari perkembangan mazhab-mazhab fikih yang terus berkembang dan menyebar. Sementara perkembangan mazhabmazhab fikih jelas sangat dipengaruhi dan didukung oleh usul fikih yang ada dalam setiap mazhab tersebut. Atas dasar itu, maka pembahasan tentang perkembangan hukum Islam hingga era modern tidak dapat dilepaskan dari pengkajian tentang wawasan mazhab fikih dan usul fikih yang berkembang di setiap kawasan yang menjadi titik-titik eksistensi komunitas muslim.

Pembahasan tentang wawasan mazhab fikih pada suatu kawasan tentu pula tidak lepas dari kajian tentang sejarah awal kehadiran mazhab fikih itu sendiri. Sebagaimana diketahui, bahwa Mekkah dan Madinah merupakan dua kawasan pusat kehadiran Islam pada awal mulanya. Teks-teks wahyu-baik berupa al-Quran maupun al-Sunnahsemuanya diturunkan atau hadir dalam kehidupan sosial kedua kawasan sentral tersebut serta tempat-tempat yang mengitarinya-seperti lokasi-lokasi peperangan Nabi saw yang berada di luar Mekkah dan Madinah-.

Proses penyebaran fikih Islam pasca generasi sahabat Nabi saw. dan

${ }^{1}$ Umar bin Sulaimān al-Asyqar, alMadkhal ilā Dirāsah al-Madāris wa al-Mażāhib alFiqhiyyah (cetakan 1: 'Amman, Dār al-Nafā'is, 1416 H), h. 11. Menurutnya pula bahwa kedua madrasah ini pada mulanya dinisbatkan kepada 2 nama kota di mana masing-masing metodologi ini berakar, yaitu: Madinah dan Kufah; sehingga kedua metodologi tersebut mulanya lebih dikenal dengan istilah Madrasah Ahl al-Madinah dan Madrasah Ahl al-Küfah. Namun ketika kedua metodologi ini telah demikian berkembang luas ke berbagai kawasan Islam, di mana para pengikut kedua manhaj tersebut tidak lagi dibatasi oleh teritorial, peristilahan tersebut dinilai tidak lagi generasi täbi'ìn dan atbä' al-täbi'in kemudian dengan sangat cemerlang mengukuhkan setidaknya 2 madrasah (baca: metodologi fikih) besar: Madrasah Abl al-Hadis dan Madrasah Abl al-Ra'y. ${ }^{1}$

Dari kalangan Madrasah Abl al-

Hadiss, sejarah Fikih Islam mencatat mazhab-mazhab seperti Mālikiyah, Syāfi'iyah, Ḥanbaliyah, Rahāwiyah (dinisbatkan kepada Isḥāq bin Rahawaih) dan Khuzamiyah (dinisbatkan kepada Muhammad bin Khuzaimah). ${ }^{2}$ Di samping itu juga tercatat nama-nama fuqaha' Abl al-Hadìs yang juga memiliki pengikut, seperti: Yahyya bin Sa'īd al-Qatțān, Wakì bin alJarraḥ, Sufyān al-Śaurī, al-Awzā, Ibnu Jarīr al-Ṭabarī, al-Bukhārī dan Muslim. ${ }^{3}$ Adapun dari kalangan Madrasah Abl alRa'y, tercatat para fuqaha' cemerlang seperti-tentu saja-Abū Hanīfah alNu'mān bin Śabit, Muḥammad bin alHasan, Abū Yūsuf al-Qādī, Zufar bin al-Hużail, dan al-Hasan bin Ziyīd. ${ }^{4}$

Mazhab-mazhab itu tentu saja tidak bernasib sama. Beberapa mazhab fikih kemudian tidak berkembang dan tersebar. Namun sebagian mazhab lainnya -seperti al-Mażähib al-Arba'ab atau mazhab yang empat-ternyata berhasil bertahan, mengembangkan diri dan menyebar ke berbagai tempat.

relevan. Itulah yang kemudian menyebabkan lahirnya istilah Madrasah Ahl al-Hadīs dan Ahl al$R a^{\prime} y$.

2 Ibnu Qayyim al-Jawziyah, jilid II I'lām al-Muwaqqi'īn 'an Rabb al-'Ālamīn, ed. Muhammad Muhy al-Din (Beirut: al-Maktabah al'Așriyyah, 1413 H), h. 283.

3 Abu Zahrah, al-Hadiss wa alMuḥaddis̄ūn (Kairo: Maktabah Wahbah), h. 387.

${ }^{4}$ Al-Syahrastani, al-Milal wa al-Nihal, jilid 1 (Cet. II: Beirut, Dār al-Ma'rifah, 1395 H), h. 207. 
Penyebaran mazhab-mazhab yang tersisa itu bergerak seiring dengan irama pergerakan penyebaran Islam ke berbagai penjuru dunia. Termasuk di antaranya Asia Tenggara.

Berdasarkan latar belakang masalah yang telah dipaparkan sebelumnya, maka rumusan utama masalah penelitian ini adalah: bagaimana wawasan mazhab fikih dan usul fikih di Asia Tenggara. Dengan tujuan agar pembahasan menjadi lebih sistematis, maka rumusan masalah utama tersebut akan diuraikan sesuai sistematik sub-sub masalah berikut:

1. Bagaimana sejarah masuknya fikih dan usul fikih di Asia Tenggara?

2. Bagaimana eksistensi fikih dan usul fikih yang tersebar di Asia Tenggara?

3. Bagaimana pengaruh mazhab fikih dan usul fikih terhadap produk hukum Islam di Asia Tenggara?

\section{PEMBAHASAN}

\section{A. Sejarah Masuknya Fikih dan Usul Fikih di Asia Tenggara}

Asia Tenggara adalah kawasan yang meliputi beberapa negara, yaitu: Indonesia, Malaysia, Thailand, Kamboja, Laos, Vietnam, Myanmar, Singapura, Brunei Darussalam dan Filipina. Disebabkan keterbatasan data penelitian, maka pembahasan ini hanya akan menyinggung negara-negara tertentu, seperti: Indonesia, Malaysia, Thailand, Singapura, Brunei Darussalam dan Filipina.

Sejarah masuknya fikih dan usul fikih (selanjutnya akan disebut

5 Azyumardi Azra, Jaringan Ulama Timur Tengah dan Kepulauan Nusantara Abad XVII \& XVIII (Cet. 3: Prenada Media, Jakarta, 2007), h. 2-3.

6 C.S. Hurgronje, Verspreide Geschriften, jilid VI (Nijhoff; Den Haag, 1924), h. "fikih" saja) ke kawasan ini tidak dapat dilepaskan dari sejarah kehadiran Islam yang dibawa oleh para penyebarnya ke kawasan tersebut. Berbicara tentang sejarah kehadiran dan masuknya Islam di kawasan Asia Tenggara secara umum dapat dijelaskan melalui beberapa teori:

1. Teori Anak Benua India (Teori Gujarat-Malabar dan Teori Bengal):

Teori ini dikemukakan oleh sejumlah sarjana yang kebanyakannya adalah sarjana orientalis Belanda, seperti Pijnappel dan Snouck Hurgronje. Menurut teori ini, asal muasal kehadiran Islam di kawasan Nusantara adalah wilayah Gujarat dan Malabar. Adalah orang-orang Arab bermazhab Syafi'i yang bermigrasi dan menetap di wilayah Anak Benua India tersebut yang kemudian membawa Islam ke Nusantara.

Menurut Hurgronje, ketika Islam telah berpijak kokoh di kota pelabuhan Anak Benua India, kaum muslim pendatang kemudian datang ke Dunia Melayu sebagai pedagang dan sekaligus menjadi penyebar Islam generasi awal. Hurgronje sendiriberbeda dengan Pijnappel-tidak secara spesifik menyebutkan wilayah Anak Benua India mana yang ia pandang sebagai asal Islam di Nusantara, namun ia mengklaim bahwa abad ke-12 Masehi sebagai periode paling mungkin dari awal penyebaran Islam di Nusantara. ${ }^{6}$

Sementara Moquette, seorang sarjana Belanda lainnya, berkesimpulan bahwa tempat asal Islam di Nusantara adalah Gujarat. ${ }^{7}$ Alasan Moquette dalam hal ini adalah didasarkan pada

7, sebagaimana dalam Azyumardi Azra, Jaringan Ulama Timur Tengah dan Kepulauan Nusantara Abad XVII \& XVIII, h. 3.

7 J.P. Moquette, De Grafsteenen te Pase en Grisse Vergleken Met Dergelijke Monumenten uit Hindoestan (TBG, 1912), h. 536, sebagaimana 
Website: https://journal.stiba.ac.id

ISSN : 2685-7537 (online) 2338-5251 (Printed)

adanya kemiripan antara batu nisan yang ditemukan di Pasai (khususnya yang bertanggalkan 17 Dzulhijjah 831 H/27 September 1428 M) dan batu nisan makam Maulana Malik Ibrahim (w. $822 \mathrm{H} / 1419$ M) di Gresik dengan bentuk batu nisan yang terdapat di Cambay, Gujarat. Menurutnya, ada kemungkinan batu nisan itu adalah produksi Gujarat yang kemudian diimpor ke wilayah lain termasuk Sumatra dan Jawa.

Namun kesimpulan Moquette kemudian dibantah oleh Fatimi. Dalam hal ini, Fatimi sepakat dengan Moquette untuk menggunakan "Teori Batu Nisan" terkait penyimpulan asal muasal Islam di Nusantara, namun ia berpandangan bahwa batu nisan yang disimpulkan Moquette memiliki kemiripan dengan bentuk batu nisan Gujarat sebenarnya justru lebih mirip dengan batu nisan yang terdapat di Bengal. Karenanya, ia menyimpulkan bahwa asal muasal Islam di Nusantara adalah wilayah Bengal. ${ }^{8}$

\section{Teori Arabia:}

Beberapa peneliti lain tidak sepakat dengan Teori Anak Benua India sebagai asal muasal kehadiran Islam di Nusantara. Marrison, misalnya, menyatakan bahwa meski batu nisan yang ditemukan di tempattempat tertentu di Nusantara berasal dari Gujarat atau dari Bengal, itu tidak lantas berarti bahwa Islam juga dihadirkan ke Nusantara dari kawasan

dalam Azyumardi Azra, Jaringan Ulama Timur Tengah dan Kepulauan Nusantara Abad XVII \& XVIII , h. 3.

8 SQ. Fatimi, Islam Comes to Malaysia (Singapore: Malaysian Sosiological Institute, 1963), h. 31-32, sebagaimana dalam Azyumardi Azra, Jaringan Ulama Timur Tengah dan Kepulauan Nusantara Abad XVII \& XVIII, h. 4.

${ }^{9}$ G.E. Marrison, The Coming of Islam to The East Indies (Cet. 1: JMBRAS, 1954), h. 24, itu. Kenyataannya adalah bahwa ketika terjadi proses Islamisasi di wilayah Samudra Pasai yang raja pertamanya wafat pada tahun 1297 M, saat itu Gujarat masih merupakan kerajaan Hindu. Gujarat baru dapat ditaklukkan oleh kekuasaan Muslim setahun kemudian, yaitu pada tahun 1298 M. Logikanya, menurut Marrison, jika Islam di Nusantara berasal dari Gujarat (atau dari Kawasan Anak Benua India manapun), maka Islam pastilah telah berada dalam posisi yang mapan dan berkembang di kawasan tersebut sebelum wafatnya raja pertama Samudra Pasai, Malik al-Shaleh, pada tahun 1297 M. ${ }^{9}$

Jauh sebelum Marrison, T.W. Arnold berpandangan bahwa para pedagang Arab yang berasal langsung dari kawasan Arabia telah melakukan penyebaran Islam sejak abad-abad awal Hijriyah atau sekitar abad ke-7 dan ke8 Masehi. Asumsi ini didukung oleh apa yang disebutkan oleh sumbersumber Cina, bahwa menjelang abad ke-7 seorang pedagang Arab menjadi pemimpin sebuah pemukiman Arab Muslim di salah satu pesisir pantai Sumatra. Sebagian pendatang Arab ini juga dilaporkan melakukan perkawinan dengan wanita lokal, sehingga membentuk jaringan kecil komunitas Muslim yang terdiri dari kaum Arab pendatang dan penduduk lokal. ${ }^{10}$ Terkait "Teori Arabia" ini, Niemann dan de Hollander secara spesifik

sebagaimana dalam Azyumardi Azra, Jaringan Ulama Timur Tengah dan Kepulauan Nusantara Abad XVII \& XVIII, h. 5.

10 T.W. Arnold, The Preaching of Islam: A History of The Propagation of The Muslim Faith (London: Constable, 1913), h. 364-365, sebagaimana dalam Azyumardi Azra, Jaringan Ulama Timur Tengah dan Kepulauan Nusantara Abad XVII \& XVIII, h. 6. 
Website: https://journal.stiba.ac.id

ISSN : 2685-7537 (online) 2338-5251 (Printed)

menegaskan bahwa asal muasal Islam di Nusantara berasal dari Hadramaut. ${ }^{11}$ Hal ini juga ditegaskan oleh sejarawan Muslim Hadramaut, Saqqaf al-Kaf. ${ }^{12}$

Dalam menimbang kedua teori ini, penulis sepakat dengan upaya kompromi yang dilakukan Azyumardi Azra terhadap kedua teori ini, yaitu bahwa mungkin benar Islam telah diperkenalkan dan mulai ada di kawasan Nusantara sejak abad-abad pertama Hijriyah (sekitar abad ke-7 Masehi), namun hanya setelah abad ke12 pengaruh Islam mulai tampak lebih nyata dan jelas. Karena itu, kemungkinan besar pada kisaran abad ke-12 hingga abad ke-16 barulah terjadi sebuah proses akselerasi Islamisasi di kawasan Nusantara. ${ }^{13}$

Hal penting yang perlu dicatat di sini adalah bahwa baik "Teori Anak Benua India" maupun "Teori Arabia", keduanya sama-sama melandaskan asumsinya pada adanya kesamaan mazhab fikih antara kawasan Asia Tenggara dengan kawasan-kawasan yang disebutkan dalam teori-teori tersebut, yaitu Mazhab Syafi'i. ${ }^{14}$

Kehadiran Mazhab Syafi'i sebagai mazhab fikih yang eksis di kawasan Nusantara juga dicatat oleh Ibnu Batutah yang mengatakan:

11 Azyumardi Azra, Jaringan Ulama Timur Tengah dan Kepulauan Nusantara Abad XVII \& XVIII, h. 7-8.

12 Saqqaf al-Kaf, Hadramawt 'Abr Arba'ah 'Asyar Qarnan, h. 58, sebagaimana dalam Muhammad bin 'Umar al-Kaf, Intisyār al-Mażhab al-Syāfi'i $\quad$ fi $\quad$ al-'Ālam al-Is/āmī, http://www.feqhweb.com/vb/showthread.php?t $=3368 \& p=16246 \&$ viewfull=1\#post 16246 .

Diakses pada tanggal 2 April 2011.

13 Azyumardi Azra, Jaringan Ulama Timur Tengah dan Kepulauan Nusantara Abad XVII \& XVIII, h. 12.

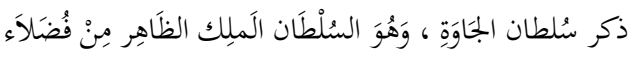

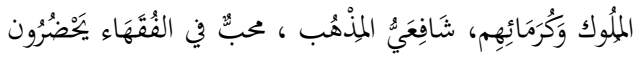

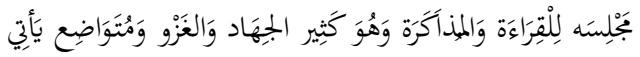

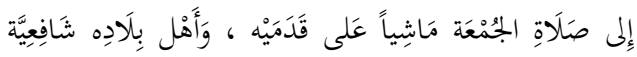

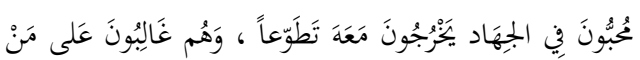

$$
\begin{aligned}
& \text { يليهم مِن الكُفَّار. } 15
\end{aligned}
$$

Artinya:

Tentang Sultan Jawa, beliau adalah Sultan al-Malik al-Zahir, termasuk seorang raja yang mulia dan dermawan. Ia bermazhab Syafi'i. Begitu mencintai para fuqaha' yang hadir di majlisnya untuk membacakan (kitab) dan melakukan muz.|a>karah. Dan beliau juga sangat sering berjihad dan peperangan, dan juga sosok yang tawadhu'. Beliau biasa datang mengerjakan shalat Jumat dengan berjalan kaki. Dan penduduk negrinya (semuanya) bermazhab Syafi'i. Mereka juga mencintai (senang) beriihad. Mereka keluar (berjihad) bersamanya (Sultan) dengan suka rela. Dan mereka menang dalam menghadapi orangorang kafir.

${ }^{14} \mathrm{Hal}$ ini sekaligus menjadi alasan yang melemahkan asumsi Fatimi tentang Bengal sebagai asal Islam di Nusantara mengingat mazhab fikih yang menyebar di kawasan Bengal adalah mazhab Hanafi. Azyumardi Azra, Jaringan Ulama Timur Tengah dan Kepulauan Nusantara Abad XVII \& XVIII, h. 4, 6 .

15 Ibnu Batutah, Tuhfah al-Nažzār fi Garā'ib al-Amșār wa 'Ajā'ib al-Asfār, edt: 'Abd alHadi al-Tazi, jilid 4 (Maroko: Matbu'at Akadimiyyah al-Mamlakah al-Magribiyyah, 1997 M), h. 114.

Mahmood Zuhdi Haji Abd. Majid, Mazhab Syafi'i di Malaysia, 
Dengan demikian, berdasarkan gambaran awal kehadiran Islam di kawasan Asia Tenggara dapat disimpulkan bahwa mazhab fikih dan usul fikih yang dibawa oleh para penyebar Islam awal adalah Mazhab Syafi. Mazhab inilah yang kemudian mewarnai perjalanan hukum Islam di kawasan ini hingga memasuki fase pembaruan Islam era modern, yang perlahan-lahan mulai terbuka dengan pandangan-pandangan lain di luar Mazhab Syafi'i itu sendiri.

\section{B. Eksistensi Mazhab Fikih dan Usul Fikih di Asia Tenggara}

Menurut Mahmood Zuhdi, negri kawasan Asia Tenggara yang paling pertama diketahui berpegang pada Mazhab Syafi'i adalah Samudra Pasai. Raja Samudra Pasai, Merah Silu kemudian masuk Islam melalui seorang ulama Mekkah yang bernama Syekh Ismail al-Siddiq. Merah Silu kemudian berganti nama menjadi Sultan Malik alSalih, dan sejak saat itu Mazhab Syafi'i menjadi mazhab yang paling awal diperkenalkan di Nusantara. ${ }^{16}$ Ketika Ibnu Batutah singgah di Pasai pada tahun 1345 M-sebagaimana telah disinggung sebelumnya-, ia menemukan Sultan Malik al-Zahir dan rakyatnya menganut Mazhab Syafi'i. Di Pasai, Ibnu Batutah juga mengaku bertemu dengan dua orang ulama mazhab Syafi'i, Amir ibn Sa'id alSyirazi dan Taj al-Din al-Isfahani. ${ }^{17}$

${ }^{16}$ Mahmood Zuhdi Haji Abd. Majid, "Mazhab Syafi'i di Malaysia", dalam Jurnal Fiqh, University of Malaya. Academy of Islamic Studies. Dept. of Figh and Usul, edisi 4, tahun 1, .h. 3.

${ }^{17}$ Abdul Rahman Haji Abdullah, Pemikiran Umat Islam di Nusantara (Kuala Lumpur: Dewan Bahasa dan Pustaka, 1990), h. 119.
Pasai pada waktu itu dapat dikatakan menjadi tujuan utama para pelajar di kawasan Nusantara untuk menuntut ilmu, khususnya ilmu fikih Syafi'i. Bahkan beberapa tokoh ulama Pasai ketika itu telah melakukan perjalanan dakwah dan mengajar ke berbagai wilayah yang ada di kawasan Asia Tenggara itu, seperti Syekh Said Sari yang disebut-sebut berhasil mengislamkan Raja Patani, Phya Tu Nakpa, yang kemudian mengganti namanya menjadi Sultan Islam Żillullāh fî al-'Ālam. ${ }^{18}$

Sezaman dengan Kerajaan Pasai ini patut dicatat Kerajaan Terengganu. Salah satu bukti sejarah yang masih tersisa dari kerajaan Melayu ini adalah sebuah batu tulis yang ditemukan di Kuala Berang, Terengganu pada tahun 1898 M. Di dalam batu tulis yang bertanggal 17 Rajab $702 \mathrm{H}$ (bertepatan dengan 22 Februari $1303 \mathrm{M}$ ) itu tertulis 10 peraturan yang harus dilaksanakan oleh kerajaan tersebut. Di antara peraturan yang termaktub pada batu itu adalah tentang hukum rajam bagi pezina, larangan mengingkari pembayaran hutang, dan sebagainya. Singkatnya apa yang termaktub di dalam batu tulis tersebut ternyata menjadikan Mazhab Syafi'i sebagai landasannya. ${ }^{19}$

Baik Kerajaan Pasai maupun Kerajaan Terengganu pada akhirnya mulai melemah kekuatan politiknya, bahkan Terengganu sendiri kemudian tumbang akibat serangan Kerajaan

${ }^{18}$ Mahmood Zuhdi Haji Abd. Majid, "Mazhab Syafi'i di Malaysia", dalam Jurnal Fiqh, 3-4.

${ }^{19}$ Syed Mohd Naquib al-Attas, The Correct Date of The Terengganu Inscription (Kualam Lumpur: Muzium Negara, 1970), h. 43, sebagaimana dalam Mahmood Zuhdi Abd Majid, "Mazhab Syafi'i di Malaysia", dalam Jurnal Fiqh, h. 4 . 
Majapahit pada abad ke 14. Pasai sendiri akibat kelemahan itu tidak lagi mampu tampil sebagai pusat pengembangan ilmu-ilmu Islam. Hal itu kemudian menyebabkan pusat pengkajian dan pengembangan Islam berpindah ke Malaka, tepatnya di bawah naungan Kerajaan Malaka (1400-1511). Di situlah Mazhab Syafi'i kemudian melanjutkan perkembangannya setelah sempat meredup..$^{20}$

Salah satu peninggalan hukum penting kerajaan Malaka adalah Undang-undang Malaka, yang kemudian diikuti dengan Undangundang wilayah yang lahir di bawah pengaruhnya, seperti Undang-undang Pahang dan Undang-undang Johor. Hal penting yang harus ditegaskan dalam tulisan ini adalah bahwa sebagian kandungan undang-undang tersebut berasaskan hukum Islam, khususnya Fikih Mazhab Syafi'i. ${ }^{21}$

Eksistensi Mazhab Syafi'i di kawasan Asia Tenggara semakin jelas dengan kehadiran beberapa referensi utama dalam mazhab tersebut. Di antara referensi utama itu adalah kitab Minhäj al-Tälibin karya al-Imam alNawawi (676 H/1277 M). Buku ini pertama kali dibawa masuk ke kawasan ini melalui Kerajaan Pasai pada abad ke 13. ${ }^{22}$ Buku lain yang patut disebut adalah kitab al-Mubzizab karya al-Imam al-Syirazi (476 H/1083 M).

Referensi utama lain dalam Mazhab Syafi'i yang menjadi rujukan banyak kaum muslimin di Nusantara adalah Fath al-Wabhab karya Abu

${ }^{20}$ Mahmood Zuhdi Abd Majid, "Mazhab Syafi'i di Malaysia", dalam Jurnal Fiqh, h. 5.

21 M.B. Hooker, Islamic Law ini Southeast Asia (Singapore: Oxford University Press, 1984), h. 11-13, sebagaimana dalam Mahmood Zuhdi, "Mazhab Syafi'i di Malaysia", dalam Jurnal Fiqh, h. 5.
Zakariya al-Ansari $(1518 \mathrm{H})$, yang juga merupakan murid dari salah satu ulama Nusantara, Abd Rauf Singkel, yang berperan langsung dalam penyebaran Fikih Syafi'i di kawasan itu. ${ }^{23}$ Kitab lain yang juga tidak boleh dilupakan adalah Fath al-Mu'in karya seorang ulama Mazhab Syafi'i yang berasal dari Malibar, Zain al-Din al-Malibari (w. 1564) yang merupakan murid dari Ibnu Hajar al-Haitami (w. 1566). ${ }^{24}$

Dengan demikian, dapat dilihat bahwa Mazhab Syafi'i telah menguasai sepenuhnya kajian-kajian hukum Islam-bahkan pengamalannya-di kawasan Nusantara, sejak Islam pertama kali hadir hingga setidaknya era Kerajaan Malaka yang mewarisi kekuatan politis kerajaan-kerajaan Islam di Asia Tenggara sebelumnya. $\mathrm{Hal}$ ini mengingat pengajaran dan pengamalan fikih di kawasan ini sangat identik dengan Mazhab Syafi'i sendiri. Bahkan jika disebutkan istilah "hukum Islam" atau "Syariat" misalnya, maka yang dimaksud tidak lain adalah hukum yang berdasarkan pada Mazhab Syafi'i. Selain itu, mazhab ini juga menjadi landasan dan pijakan dalam pembentukan birokrasi urusan keagamaan dalam pemerintahan. Semua pegawai kerajaan dalam bidang keagamaan, seperti mufti, kadi, imam dan sebagainya terdiri dari mereka yang telah terdidik dalam mazhab ini. Demikian pula dengan semua undangundang dan peraturan yang berkaitan dengan agama Islam, tidak lepas dari

22 Abdul Rahman Haji Abdullah, Pemikiran Umat Islam di Nusantara, h. 120.

23 Mahmud Junus, Sejarah Islam di Minangkabau (Jakarta: al-Hidayah, 1971), h. 10.

${ }^{24}$ Mahmood Zuhdi Abd Majid, "Mazhab Syafi'i di Malaysia", h. 6. 
pandangan-pandangan dalam mazhab ini. $^{25}$

Perkembangan Mazhab Syafi'i di Nusantara kemudian berlanjut pada zaman pemerintahan Aceh Darussalam (1205-1675 M); kerajaan Islam yang didirikan oleh Johan Syah pada tahun 1205 dan mencapai kegemilangannya di masa pemerintahan Sultan Ali Mughayat Syah (1511-1530). Kerajaan ini dapat dikatakan "mewarisi" kekuasaan Kerajaan Malaka yang berhasil dikalahkan oleh Portugis pada tahun 1511. Akibat kejatuhan Malaka itu, pedagang-pedagang kemudian banyak yang berpindah ke Aceh. Kerajaan Aceh kemudian menjadi pusat pengkajian Islam terpenting di kawasan Asia Tenggara, terutama pada abad ke-17 M ketika banyak ulama berada di sana. Dalam hal ini, kajiankajian fikih yang dibahas adalah Mazhab Syafi'i. ${ }^{26}$

Setidaknya dalam era ini, terdapat tiga nama tokoh besar ulama Aceh yang menonjol pada waktu itu, yaitu: Nur al-Din al-Raniri, Abd al-Rauf Singkel dan Jalal al-Din al-Tursani. Ketiga tokoh ini adalah para ulama yang pernah memegang jabatan "Syekh al-Islam" di kerajaan tersebut. Nur alDin al-Raniri menulis kitab al-Sirat alMustaqim; sebuah kitab fikih dalam Mazhab Syafi'i yang menguraikan hukum ibadah khusus, seperti salat, puasa, zakat dan haji. Kitab ini dianggap sebagai kitab yang pertama kali ditulis di kawasan Asia Tenggara, yaitu pada tahun $1634 \mathrm{M} .{ }^{27}$ Abd al-Rauf Singkel juga menulis sebuah kitab yang

\footnotetext{
${ }^{25}$ Mahmood Zuhdi Abd Majid, "Mazhab Syafi'i di Malaysia", h. 7.

${ }^{26}$ Mahmood Zuhdi Abd Majid, "Mazhab Syafi'i di Malaysia", h. 7.

27 Zalila Sharif dan Jamilah Haji Ahmad, Sastera Melayu Tradisional (Kuala Lumpur: Dewan Bahasa dan Pustaka, 1993), h. 397,
}

cukup popular, Mir'āt al-Tulläb; sebuah kitab dalam Mazhab Syafi'I yang lebih lengkap bahasannya dibandingkan karya al-Raniri. Tidak sekedar membahas persoalan ibadah khusus, namun juga menjelaskan tentang muamalat, muäkahāt, dan jināyah. Diperkirakan kitab ini ditulis pada tahun 1672. Sementara Jalal al-Din alTursani menulis kitab Safinah alHukkām yang menjelaskan seputar persoalan muamalat, jinayjah dan hal-hal yang berkait urusan pemerintahan dan tata negara, seperti bab al-Qad $\vec{a}$ ' atau peradilan. Kitab ini ditulis pada masa pemerintahan Sultan Alauddin Johan Syah $(1760 \mathrm{M})$. Tujuan utama penulisan kitab ini adalah untuk menjadi panduan bagi para hakim dan kadi di mahkamah. ${ }^{28}$

Selain ketiga ulama tersebut, terdapat pula beberapa ulama lain di Kerajaan Aceh, antara lain: ${ }^{29}$

a. Jamal al-Din al-Tursani-putra dari Jalal al-Din al-Tursani-menulis kitab Hidāyah al-'Awām, sebuah kitab fikih yang diawali dengan pembahasan tentang "Sifat Dua Puluh".

b. Seorang ulama bernama Jalal al-Din menulis kitab Farä'id al-Qur'ān; sebuah kitab yang membahas tentang hukum kewarisan.

c. Muhammad Zain ibn Jalal alDin menulis kitab Kasyf al-Kiräm, yang membahas tentang niat dan takbiratul ihram. Juga kitab Talkhiṣ al-Faläh yang menjelaskan tentang hukum pernikahan dan perceraian.

sebagaimana dalam Mahmood Zuhdi Abd Majid, Mazhab Syafi'i di Malaysia, h. 8.

${ }^{28}$ Mahmood Zuhdi Abd Majid, Mazhab Syafi'i di Malaysia, h. 8.

${ }^{29}$ Mahmood Zuhdi Abd Majid, Mazhab Syafi'i di Malaysia, h. 8-9. 
Dengan mengambil studi kasus karya-karya Abd al-Ra'uf Singkel dan al-Tursani dapat dikatakan bahwa kajian fikih Mazhab Syafi'i telah mencapai kemajuan selangkah ke depan. Ini dikarenakan kedua karya mereka dinilai disusun dengan mengambil pendekatan lokal agar dapat sesuai dengan tujuan utama penulisannya: menjadi panduan dalam urusan pemerintahan dan peradilan. ${ }^{30}$

Menurut Mahmood Zuhdi, penyebaran pengaruh fikih Mazhab Syafi'i di kawasan Asia Tenggara setidaknya dilakukan melalui dua jalur: jalur pendidikan dan jalar penaklukan. Dari jalur pendidikan misanya, fikih Mazhab Syafi'i masuk ke wilayah Minangkabau dan lahirlah sosok Burhan al-Din yang merupakan murid 'Abd al-Ra'uf Singkel, sebagaimana telah disebutkan. Sementara jalur penaklukan berperan menyebarkan Mazhab Syafi'i ke wilayah Johor (1915), Pahang (1618), Kedah (1619) dan Perak (1620). Pada masa pemerintahan Sultan Muzafar Syah di Kedah misalnya, Raja Aceh yang berkuasa mengirimkan dua buah karya al-Raniri kepadanya: al-Sirät al-Mustaqim dan Bab al-Nikāh. ${ }^{31}$

Selain ulama-ulama Kerajaan Aceh, patut dicatat pula bahwa juga terdapat tokoh-tokoh ulama Nusantara di luar Aceh yang menghasilkan karyakarya ilmiah dalam ranah fikih Mazhab Syafi'i, antara lain: ${ }^{32}$

a. 'Abd al-Malik bin 'Abdullah (w. 1736), seorang ulama Terengganu yang pernah belajar kepada 'Abd al-

${ }^{30}$ Mahmood Zuhdi Abd Majid, Mazhab Syafi'i di Malaysia, h. 9.

${ }^{31}$ Zulkifli Mohd Salleh, Hikayat Merong Mahawangsa (Kuala Lumpur: Dewan Bahasa dan Pustaka, 1972), h. 149, sebagaimana dalam Mahmood Zuhdi Abd Majid, Mazhab Syafi'i di Malaysia h. 9.
Ra'uf Singkel di Aceh, kemudian kepada Syekh Ibrahim al-Kurani (1690 M) di Mekkah. Setidaknya ada dua karya yang pernah ditulisnya: Risālah Naql dan Risälab Kaifiyyah Niyyah. Kitab pertama menjelaskan tentang bilangan shalat Jumat yang sah menurut qawl qadim dan qawl jadid dalm Mazhab Syafi'i, sedangkan kitab kedua membahas tentang masalah niat di dalam ibadah.

b. Syekh Muhammad Arsyad al-Banjari (1812), seorang tokoh besar ulama fikih Mazhab Syafi'i dari negri Banjar. Setelah belajar selama 30 tahun di Mekkah, ia kemudian kembali ke kampung halamannya dan menjadi mufti pada masa pemerintahan Tahmidullah yang juga tidak lain adalah sahabatnya. Salah satu karyanya adalah Sabil al-Mubtadin li al-Tafaqquh fi Amr alDin yang ditulis pada tahun 1781. Kitab yang terdiri dari 2 jilid ini membahas masalah ibadah saja dan ditulis atas permintaan Sultan Tahmidullah yang berkuasa saat itu. ${ }^{33}$ Salah satu poin penting kitab ini adalah bahwa di dalamnya Syekh Arsyad juga menjelaskan berbagai persoalan hukum yang telah berlaku dalam masyarakat Banjar pada abad ke 18. Dengan kata lain, kitab ini telah memberikan sumbangan yang bermakna bagi perkembangan fikih Syafi'i di kawasan Nusantara karena menjadikan kondisi lokal sebagai hal yang penting untuk dibahas dalam kajian-kajian fikih.

Di wilayah lain kawasan Asia Tenggara, Patani, juga tercatat satu nama penting dalam pengembangan

32 Mahmood Zuhdi Abd Majid, Mahmood Zuhdi Abd Majid, Mazhab Syafi'i di Malaysia, h. 10.

33 Zalila Sharif dan Jamilah Haji Ahmad, Sastera Melayu Tradisional, h. 399. 
fikih Mazhab Syafi'i di kawasan ini, yaitu Syekh Daud ibn 'Abdullah alFatani. Beliau belajar di Mekkah dan tinggal cukup lama di sana. Beliau menulis banyak buku, namun khusus dalam ranah fikih ia menulis kitab Furü' al-Masä'il yang merupakan salah satu kitab fikih yang lengkap. Bahasannya meliputi aspek ibadah, muamalat, munäkahät, jināyah dan sebagainya. Menurut 'Abdul Rahman Haji Abdullah, karya ini merupakan karya puncak dalam bidang fikih di Nusantara pada waktu itu. ${ }^{34}$ Selain itu, beliau juga menulis beberapa karya di bidang fikih yang bersifat tematik, seperti: Bugyah al-Tulläb dalam masalah ibadah dan Gajyah al-Taqrīb dalam masalah waris dan 'iddah. ${ }^{35}$

Selain daripada kitab-kitab yang telah disebutkan di atas, masih terdapat beberapa kitab fikih lainnya yang pernah diterbitkan di kawasan Asia Tenggara dan masing-masing telah memainkan perannya dalam mengembangkan kajian-kajian hukum Islam, khususnya fikih Mazhab Syafi'i. Di antaranya adalah kitab Minbäj alSalām karya Muhammad Zain alBadawi al-Sambawi, Samarāt alMubimmah karya Raja Ali Haji, Kifāyah al-Gulam karya Ismail Minangkabau dan Kifāyah al-Mubtadi karya Muhammad Noor bin Muhammad bin Isma'il al-Fatani. ${ }^{36}$

Jika dilihat dari sisi rujukan dan referensi penulisan karya-karya

34 Abdul Rahman Haji Abdullah, Pemikiran Umat Islam di Nusantara, h. 122.

35 Penjelasan lebih lengkap dapat dilihat dalam Wan Mohd Saghir, Syekh Dawwud bin Abdullah al-Fatani Penulis Produktif di Asia Tenggara (Solo: CV. Ramadhani, 1987).

36 Wan Mohd Saghir Abdullah, Perkembangan IImu Fiqh dan Tokoh-Tokohnya di Asia Tenggara (Cet.1: Solo; CV. Ramadhani, 1985), h. 114-128. tersebut, dapat dikatakan bahwa secara umum kitab-kitab tersebut disusun dengan merujuk kepada karya-karya ulama Mazhab Syafi'i pada zaman taklid. Kitab al-Sirät al-Mustaqim karya al-Raniri misalnya menggunakan sumber-sumber seperti Minhäj alTälibin karya al-Nawawi, Minbäj alTulläb dan Fath al-Wabhäb karya Abu Zakariya al-Ansari, Mukbtașar al-Fatāwa karya Ibnu Hajar al-Haitami, dan Umdah al-Sälike wa Uddab al-Nāsike karya Syihab al-Din Ahmad al-Naqib. Kemudian Mir'āh al-Tulläb karya 'Abd al-Rauf Singkel menggunakan Tuhfah al-Muhtāj karya Ibnu Hajar al-Haitami dan Nibāyah al-Minhäj karya Syams alDin al-Ramli. ${ }^{37}$

Hal ini sekali lagi menunjukkan bahwa pengaruh Mazhab Syafi'i di kawasan Asia Tenggara dapat dikatakan hampir menyeluruh. Meskipun tidak semua Mazhab Syafi'i telah diwakili secara menyeluruh dalam memberikan pengaruhnya terhadap kajian-kajian fikih di Nusantara, karena kitab-kitab yang menjadi rujukan hanya yang ditulis pada zaman taklid saja. Karya-karya al-Imam al-Syafi'i sendiriseperti al-Umm dan al-Risälah-tidak dijadikan sebagai rujukan. ${ }^{38}$

Dari perspektif ini, maka dapat disimpulkan bahwa yang dimaksudkan dengan Mazhab Syafi'i yang tersebar luas di kawasan Asia Tenggara sebenarnya lebih banyak mewakili

37 Cik Hasan Basri, Model Penelitian Fiqh, jilid II (Cet.1: Jakarta; Prenada Media, 2003), h. 298-300. Bandingkan juga dengan Haidar Putra Daulay, Dinamika Pendidikan Islam di Asia Tenggara (Cet. 1: Jakarta; Rineka Cipta, 2009), h.75-77.

38 Mahmood Zahid Abd Majid, Mazhab Syafi'i di Malaysia, h. 13 
"aliran" al-Nawawi saja. Kitab-kitab tersebut dianggap memiliki otoritas yang sangat kuat di zaman taklid karena dianggap sebagai karya puncak pada era tersebut. Apalagi seruan untuk bertaklid sangat digaungkan dalam berbagai kitab Usul Fikih yang ditulis pada waktu itu. ${ }^{39}$

\section{Pengaruh Mazhab Fikih dan Usul Fikih Terhadap Produk- produk Hukum Islam di Asia Tenggara}

Dengan gambaran eksistensinya sebagaimana telah dijelaskan terdahulu, tidak dapat dielakkan bahwa fikih Mazhab Syafi'i di kawasan Asia Tenggara pasti akan memberikan pengaruh bagi produkproduk hukum Islam yang dikembangkan di kawasan ini. Meskipun faktor superior-inferior dan mayoritas-minoritas umat Islam di suatu wilayah sedikit banyaknya memberikan pengaruh bagi upaya maksimalisasi produk-produk hukum Islam. Kondisi Filipina dan Thailand misalnya jelas tidak dapat disamakan dengan kondisi Malaysia dan Indonesia.

Di Indonesia misalnya, kitabkitab referensi Mazhab Syafi'i dijadikan sebagai rujukan pengadilan agama. Dalam surat edaran Biro Peradilan Agama 735 Tahun 1958, misalnya, disebutkan beberapa kitab yang dijadikan rujukan itu: al-Bäjurī, Fath alMu'in dan syarahnya, Hasyiyah Qalyubi, Fath al-Wabhab dan syarahnya, Mugni al-Mubtaj, I'anah al-Talibin, al-Mubazzab,

39 Wan Muhammad 'Ali bin 'Abd alRahman al-Kelantani, Zahrah al-Murid (Kota Bharu: al-Ahmadiyah Press, t.t.) h. 8-9, sebagaimana dalam Mahmood Zainal, Mazhab Syafi'i di Malaysia, h. 14.

40 Cik Hasan Basri, Model Penelitian Fiqh, h. 298.
Kifayah al-Akbyar, dan lain-lain. ${ }^{40}$ Dalam perkembangan selanjutnya, sebagaimana telah diketahui, kitabkitab itu juga menjadi rujukan utama dalam penyusunan Kompilasi Hukum Islam di Indonesia.

Dalam perkembangan selanjutnya, hukum Islam di Asia Tengara terdapat dua kecenderungan yang menonjol yang berkaitan dengan perkembangan hukum Islam itu sendiri, yaitu:

1. Hukum Islam telah berubah dan bergeser dari orientasinya yang menekankan persoalan ibadah menuju persoalan muamalah. Perdebatan hukum saat ini sudah tidak lagi dipenuhi oleh masalah ibadah saja seperti batalnya wudhu seseorang jika bersentuhan dengan lawan jenisnya, tetapi sudah merambah ke persoalan-persoalan halal haramnya makanan atau ekonomi syari'ah.

2. Penyadaran hukum tidak hanya satu mazhab, tetapi diperluas untuk melihat dan merujuk ke pelbagai mazhab fikih yang ada. ${ }^{41}$

Cakupan masalah hukum Islam di Asia Tenggara sangat luas, baik materinya maupun institusi pengembangannya. Dari segi materi misalnya muncul isu hukum Islam di bidang pidana, bisnis, barang gunaan dan makanan disamping masalahmasalah yang menyangkut kewenangan pengadilan agama selama ini seperti perkawinan, perceraian dan kewarisan.

41 Haji Salim bin Haji Besar, "Pelaksanaan Undang-undang Keluarga Islam di Negara Brunei Darussalam dan Permasalahannya", dalam Mimbar Hukum, no. 22, Tahun VI, September-Oktober, 1995, h. 9. 
Dari segi institusi pengembangan hukum Islam ada masalah pengembangan mengenai eksistensi lembaga peradilan, kodifikasi dan organisasi hukum Islam. ${ }^{42}$

Di Malaysia, misalnya hukum Inggris tetap diberlakukan dan diterapkan pada sebagian legislasi dan yurisprudensi. Undang Undang Hukum Perdata 1956, menyebutkan apabila tidak didapatkan hukum tertulis maka pengadilan perdata mengikuti hukum Adat Inggris atau aturan lain yang sesuai. Dengan demikian hukum Islam hanya dapat diterapkan pada wilayah yang terbatas mengenai hal-hal yang berkaitan dengan hukum keluarga dan pelanggaran agama yang hanya berlaku untuk orang Islam.

Bila ada pertentangan antara pengadilan perdata dengan syariah, keputusan pengadilan perdata lebih diutamakan. Pemerintah Malaysia pernah mengeluarkan kebijaksanaan untuk menyatukan prinsip-prinsip Islam dalam aspek kehidupan serta administrasi, termasuk juga hukum. Untuk itu suatu komite harus menelaah seluruh undang-undang yang ada di Malaysia dan melihat sumua kemungkinan untuk disesuaikan dengan syariah. Bila saja komite telah dibentuk, tentu akan mampu mengkodifikasi syariah di Malaysia berdasarkan pendekatan yang komprehensif serta integratif sehingga legislasi untuk membuat hukum Islam lebih efektif.

$$
\text { Sedangkan di Singapura, }
$$

Ummat Islam berusaha keras mendekati pemerintah agar mensahkan suatu undang-undang yang mengatur Hukum Personal dan

\footnotetext{
${ }^{42}$ Wahyu Setiawan, Perkembangan Mutakhir Hukum Islam di Asia Tenggara, http://www.badilag.net/index.php?option=com content\&view=article\&id=3353: perkembangan-
}

Keluarga Islam. Upaya telah ditempuh melalui perwakilan, baik perorangan maupun melalui organisasi Muslim, yang bekerja selama bertahun-tahun dan baru tahun 1966 pemerintah mengeluarkan rancangan undangundang Parlemen dan menerima UU Administrasi Hukum Islam (the Administration of Muslim Law Act 1960). Sebelum rancangan undang undang tersebut diterima, umat Islam dari berbagai mazhab diberi kesempatan untuk membuat perwakilan dan diminta untuk menghadap Komite Pemilihan Parlemen untuk mengungkapkan pandangannya terhadap UU tersebut. Setelah rancangan tersebut diterima dan UU Administrasi Hukum Islam 1966 diberlakukan, kemudian mengalami beberapa kali amandemen sesuai yang diajukan oleh Dewan Agama Islam dan selanjutnya ditambahkan ordonansi ke dalamnya. UU Administrasi Hukum Islam merupakan pengundangan Hukum Islam yang memberikan ruang gerak yang fleksibel dalam penerapan hukum syariat.

Adapun di Thailand, kodifikasi syariah yang sistimatis telah dimulai sejak tahun empat puluhan untuk diterapkan dalam masyarakat Islam di empat provinsi selatan Thailand. Kodifikasi sekarang telah tercakup dalam Undang Undang Sipil Thailand yang berkenaan dengan keluarga dan warisan, yang kandungan syariahnya bersifat inklusif mengadili kasus di antara umat Islam. Seluruh sistem berkaitan langsung dengan mazhab Syafi'i, karena mayoritas masyarakat Muslim Thai menganut mazhab ini. Pertentangan antara orang Islam

mutakhir-hukum-islam-di-asia-tenggara0608\&catid=317: pustaka-badilag\&Itemid $=674$. Diakses pada tanggal 2 April 2011. 
yang menganut mazhab yang berbeda tidak dapat diselesaikan dengan sistem peradilan yang ada karena yang digunakan hanyalah yang telah sah dikodifikasikan. Sampai kini kodifikasi syariah yang ada beserta administrasinya tidak pernah ditinjau ulang.

Sedangkan di Filipina, dalam konstitusi negara ini, wewenang untuk mendefinisikan, menjabarkan, dan membagi yurisdiksi berbagai pengadilan terletak pada Dewan Nasional. Dalam Kitab UU Perorangan Islam di Filipina yang disebutkan bahwa Pengadilan Islam Daerah dan Pengadilan Keliling Islam diatur melalui prosedur khusus yang dapat dikeluarkan Mahkamah Agung. Dalam rangka memberikan batasan yang jelas, Mahkamah Agung mengeluarkan Aturan Prosedur Khusus dalam Pengadilan Islam (Ijra'ät al-Mahkamah al-Syariab) yang disahkan oleh Mahkamah Agung Filipina pada tanggal 20 September 1985. Untuk menjaga independensi dan integritas pada umat, Kantor Mufti berada dalam naungan Mahkamah Agung dan bukan Cabang Eksekutif pemerintah. Jika muncul suatu masalah hakim harus menginterpretasikan Kitab UU Perseorangan Islam dengan mengikutsertakan pertimbangan dari sumber utama hukum Islam. ${ }^{43}$

\section{PENUTUP}

Setelah menguraikan pembahasan tentang wawasan mazhab fikih dan usul fikih di Asia Tenggara, maka ada beberapa hal yang dapat disimpulkan, yaitu:

\footnotetext{
${ }^{43}$ Wahyu Setiawan, Perkembangan Mutakhir Hukum Islam di Asia Tenggara, http://www.badilag.net/index.php?option=com content\&view=article\&id=3353: perkembangan-
}

1. Kehadiran mazhab fikih dan usul fikih di kawasan Asia Tenggara tidak dapat dilepaskan dari sejarah kehadiran Islam pertama kali di kawasan itu. Secara umum terdapat dua teori besar yang menjelaskan kehadiran Islam awal di kawasan Asia Tenggara: Teori Anak Benua India dan Teori Arabia. Hal penting yang patut dicatat bahwa apapun teori yang dipegangi dalam menjelaskan kehadiran Islam di Nusantara, kesamaan mazhab fikih jelas menjadi salah landasan pertimbangan utama untuk menyimpulkan teori-teori tersebut.

2. Mazhab fikih dan usul fikih yang eksis di kawasan Asia Tenggara berdasarkan berbagai bukti dan realitas yang terus bertahan hingga kini adalah Mazhab Syafi'i. Meskipun mazhab tersebut belum dapat dikatakan terwakili secara sepenuhnya dalam kajian-kajian fikih dan usul fikih yang berkembang di kawasan ini. Bahkan kajian-kajian yang bersifat langsung kepada karya-karya sang pendiri mazhab, al-Imam al-Syafi'i, tidak terlalu popular jika dibandingkan dengan intensitas pengkajian terhadap karyakarya ulama mazhab, terutama yang ada dalam geneologi al-Imam al-Nawawi.

3. Mazhab Syafi sejak awal kehadirannya jelas memberikan kontribusi bagi kehadiran produkproduk hukum Islam di kawasan Asia Tenggara. Pada era kerajaan-kerajaan Islam awal di Nusantara terdapat banyak bukti yang menunjukkan pengaruh tersebut. Pengaruh itu terus berlanjut hingga era hukum Islam modern di kawasan ini. Sumbangsih fikih Mazhab Syafi'i dalam Kompilasi Hukum Islam di Indonesia misalnya

mutakhir-hukum-islam-di-asia-tenggara0608\&catid=317: pustaka-badilag\&ltemid=674. Diakses pada tanggal 2 April 2011. 
menjadi bukti yang paling jelas atas hal tersebut.

\section{DAFTAR PUSTAKA}

Abdul Rahman Haji Abdullah, Pemikiran Umat Islam di Nusantara (Kuala Lumpur: Dewan Bahasa dan Pustaka, 1990)

Abu Zahrah, al-H|adi>s $\mid$ wa al$M u h \mid$ addis $\mid u>n \quad$ (Kairo: Maktabah Wahbah)

Al-Asyqar, 'Umar bin Sulaima $>\mathrm{n}$, alMadkhal ila> Dira $>$ sab alMada $>$ ris wa al-Maz. $\mid a>b i b$ alFiqhiyyah (cetakan 1: 'Amman, Da $>$ r al-Nafa >'is, $1416 \mathrm{H}$ )

Azra, Azyumardi. Jaringan Ulama Timur Tengah dan Kepulauan Nusantara Abad XVII \& XVIII (Cet. 3: Prenada Media, Jakarta, 2007)

Cik Hasan Basri, Model Penelitian Fiqh, jilid II (Cet.1: Jakarta; Prenada Media, 2003)

C.S. Hurgronje, Verspreide Geschriften, jilid VI (Nijhoff; Den Haag, 1924)

G.E. Marrison, The Coming of Islam to The East Indies (Cet. 1: JMBRAS, 1954)

Haidar Putra Daulay, Dinamika Pendidikan Islam di Asia Tenggara (Cet. 1: Jakarta; Rineka Cipta, 2009)

Haji Salim bin Haji Besar, "Pelaksanaan Undang-undang Keluarga Islam di Negara Brunei Darussalam dan Permasalahannya", dalam Mimbar Hukum, no. 22, Tahun VI, September-Oktober, 1995, h. 9.

Ibnu Batutah, Tub $\mid$ fah al-Naz\} z $\} a>r f i$ Gara>ib al-Ams $\mid a>r$ wa 'Aja >'ib al-Asfa $>r$, edt: 'Abd alHadi al-Tazi, jilid 4 (Maroko: Matbu'at Akadimiyyah al-
Mamlakah al-Magribiyyah, 1997 M)

Ibnu Qayyim al-Jawziyah, I'la $>m$ alMuwaqqi'i>n 'an Rabb al'A>lami $>n$, ed. Muhammad Muhy al-Din, jilid 4 (Beirut: alMaktabah al-'As\}riyyah, 1413 $\mathrm{H})$

J>>.P. Moquette, De Grafsteenen te Pase en Grisse Vergleken Met Dergelijke Monumenten uit Hindoestan (TBG, 1912)

Mahmood Zuhdi Haji Abd. Majid, "Mazhab Syafii di Malaysia", dalam Jurnal Fiqh, University of Malaya. Academy of Islamic Studies. Dept. of Figh and Usul, edisi 4, tahun 1.

Mahmud Junus, Sejarah Islam di Minangkabau (Jakarta: alHidayah, 1971)

M.B. Hooker, Islamic Law ini Southeast Asia (Singapore: Oxford University Press, 1984)

Saqqaf al-Kaf, Had ramawt 'Abr Arba'ah 'Asyar Qarnan, h. 58, sebagaimana dalam Muhammad bin 'Umar al-Kaf, Intisya $>r$ al-Maz|hab alSya $>$ fi'i> fi> al-'A<lam alIsla $>$ mi $>$, http:/ / www.feqhweb .com/vb/showthread.php?t=3 $368 \& \mathrm{p}=16246 \& v i e w$ full $=1 \# \mathrm{p}$ ost16246.

SQ. Fatimi, Islam Comes to Malaysia (Singapore: Malaysian Sosiological Institute, 1963)

Al-Syahrastani, al-Milal wa al-Nib|al, jilid 1 (Cet. II: Beirut, Da>r alMa'rifah, $1395 \mathrm{H}$ )

Syed Mohd Naquib al-Attas, The Correct Date of The Terengganu Inscription (Kualam Lumpur: Muzium Negara, 1970.

T.W. Arnold, The Preaching of Islam: A History of The Propagation of The 
NUKHBATUL 'ULUM : Jurnal Bidang Kajian Islam

Vol. 4, No. 2 (2018) : Hal. 120-134

Website: https://journal.stiba.ac.id

ISSN : 2685-7537 (online) 2338-5251 (Printed)

Muslim Faith (London:

Constable, 1913)

Wahyu Setiawan, Perkembangan

Mutakhir Hukum Islam di Asia

Tenggara,

http://www.badilag.net/index.

php?option $=$ com content\&vi

$\underline{\mathrm{ew}=\text { article\&id }=3353 \text { :perkemb }}$

angan-mutakhir-hukum-islam-

di-asia-tenggara-

0608\&catid $=317$ : pustaka-

badilag\&Itemid $=674$. Diakses

pada tanggal 2 April 2011.

Wan Mohd Saghir, Syekh Dawnud bin Abdullab al-Fatani Penulis Produktif di Asia Tenggara (Solo: CV. Ramadhani, 1987).

Wan Mohd Saghir Abdullah, Perkembangan Ilmu Fiqh dan Tokoh-Tokohnya di Asia Tenggara (Cet.1: Solo; CV. Ramadhani, 1985)

Wan Muhammad 'Ali bin 'Abd alRahman al-Kelantani, Zahrah al-Murid (Kota Bharu: alAhmadiyah Press, t.t.)

Zalila Sharif dan Jamilah Haji Ahmad, Sastera Melayu Tradisional (Kuala Lumpur: Dewan Bahasa dan Pustaka, 1993

Zulkifli Mohd Salleh, Hikayat Merong Mahawangsa (Kuala Lumpur: Dewan Bahasa dan Pustaka, 1972 